\title{
A “Dog-eat-dog” World: Qing Jurispractices and the Legal Inscription of Piety in Amdo
}

Un monde de conflits féroces : pratique judiciaire et réglementation légale de la religion en Amdo sous les Qing

一個狗咬狗的世界：清代安多地區法律實踐与信仰之規範

\section{Max Oidtmann}

\section{OpenEdition}

\section{Journals}

Electronic version

URL: http://journals.openedition.org/extremeorient/620

DOI: $10.4000 /$ extremeorient. 620

ISBN: 978-2-84292-558-1

ISSN: 2108-7105

Publisher

Presses universitaires de Vincennes

Printed version

Date of publication: 21 November 2016

Number of pages: 151-182

ISBN: 978-2-84292-556-7

ISSN: 0754-5010

\section{Electronic reference}

Max Oidtmann, «A "Dog-eat-dog" World: Qing Jurispractices and the Legal Inscription of Piety in Amdo », Extrême-Orient Extrême-Occident [Online], 40 | 2016, Online since 21 November 2018, connection on 01 May 2019. URL : http://journals.openedition.org/extremeorient/620 : DOI : 10.4000/ extremeorient.620 


\title{
A "Dog-eat-dog" World: Qing Jurispractices and the Legal Inscription of Piety in Amdo
}

\author{
Max Oidtmann ${ }^{l}$
}

During the final quarter of the 19th century, Qing magistrates stationed in the borderlands of Gansu province handled what appeared to be a growing and increasingly troublesome load of cases involving "Fan." ${ }^{2}$ The archives of the Xunhua subprefect (tongzhi), which are extant for the years 1872-1911, reveal that in the spring and summer months when the magistrate was in residence

1. I would like to thank Jérôme Bourgon for inviting me to spend a month at the Institut d'Asie Orientale at ENS Lyon in the spring of 2015. The original draft of this article was written at that time and benefitted enormously from conversations with Professor Bourgon and his colleagues. I would also like to thank Fabienne Jagou and Gray Tuttle for their comments on previous versions of the paper, as well as the anonymous reviewers at EOEO. Aspects of this paper were presented at the Legalizing Space in China Conference (Lyon, May 2015), a session of the "séminaire Histoire du droit chinois" (EHESS, Paris, May 2015), and the Columbia Modern China Seminar (September 2015). The acute questions I received at these events greatly improved the final paper. The remaining mistakes are entirely my own. In this article Tibetan words and names are transcribed according to the conventions of the Tibetan and Himalayan Library Simplified Phonetic Transcription of Standard Tibetan (2003). The accompanying glossary contains Wylie transcriptions of these Tibetan words and names, as well as Chinese characters. Mongol names and terms are transcribed according to the form given in Atwood 2004.

2. This essay preserves the term "Fan" in translations of Chinese-language documents. In doing so I wish to underline the degree to which the Qing concept of "Fan" was distinct from the meanings implicit in the modern label "Tibetan" (Tib. Bod pa) or "Zangzu.” During the Qing period, the term Fan was a label for people who did not fall under Mongol banner administration or the administration of the eighteen provinces of the interior. Qing officials generally assumed that the Fan shared the culture and or teachings of the Gelukpa (the "Yellow Teachings" huangjiao) with the people of Central Tibet, but the term could also at times distinguish the people of Gansu and Sichuan from the people of central Tibet. 
at the yamen - he spent the rest of the year in Lanzhou or Hezhou - he often handled dozens of matters involving Tibetans on a weekly basis. On one extraordinary August day in 1889, for instance, the register of the day's business lists 68 separate affairs, the majority of which were feuds and criminal cases involving Tibetans from both his jurisdiction and neighboring subprefectures. ${ }^{3}$

Although the Qing court had sanctioned the use of "Fan statutes" (Fan li) since the $1730 \mathrm{~s}$ and Tibetans themselves regularly sought out Qing legal forums to resolve local conflicts, these cases were anything but routine. Qing magistrates arrived with little to no experience with the Fan code. They were forced to grapple with a strange cultural and physical terrain where adjudication relied on unfamiliar interlocutors and information arrived via dubious translators. ${ }^{4}$ From the perspective of the indigenous people of the borderlands, cases that rose to the attention of Qing authorities were surely extraordinary as well. These crises often entailed the loss of life or the threat of significant bodily harm. The violence was an indication of the stakes involved: the thorniest, most intractable matters brought to the attention of Qing magistrates generally resulted from conflicts over community resources and boundaries and, almost as a rule, were entwined with the affairs of the reincarnate lama hierarchs of the region's Gelukpa monasteries.

The size and scope of the political domains of lamas such as the Jamyang Zhepas of Labrang Monastery (est. 1709) or the Shartsang lamas ${ }^{5}$ of Rongwo Monastery (est. 1342) caught late Qing officials off-guard. In 1898, the subprefect of Taozhou reported feeling humiliated by the etiquette he was forced to observe when meeting the fourth Jamyang Zhepa (1856-1916). ${ }^{6}$ The son of the governor-general of Gansu and Shaanxi provinces analogized the monastic domains of Amdo to the "Warring States (Zhanguo)" of antiquity (479-221 BCE). ${ }^{7}$ Tibetan-language chronicles such as the biographies of the

3. Qinghai sheng dang' anguan, hereafter QSDG (GX 15/07/12), 7-YJ-4058. The reference number refers to the fascicle, not an individual document. When these documents were transcribed (2009-2011), individual documents had not been catalogued. See the following registers for perhaps more typical daily workloads of 20-30 items of business: QSDG (GX/12/07/22), 7-YJ-4058; (GX 15/06), 7-YJ-4059; (GX 15/07), 7-YJ-4059.

4. In 1896, for instance, the governor-general of Shaanxi and Gansu provinces felt compelled to issue instructions about using the "Fan regulations" (Fan gui) to the Xunhua subprefect and other field officers: QSDG (GX 24/04/15), 7-YJ-4164.

5. In this essay, "lama" (Tib. bla ma) refers only to revered, reincarnate lineages of the Geluk sect.

6. QSDG (GX 24/R03/25), 7-YJ-2918.

7. Tao Baolian 2002 [1896]: 240. 
Jamyang Zhepas and other local histories minimize or otherwise downplay the influence of Qing administrators in the region. ${ }^{8}$ For these reasons, scholars have justifiably portrayed the Tibetan communities in Amdo as largely autonomous or even "independent" of Qing authority. ${ }^{9}$ The extensive archival record of litigation by these monasteries and lamas in Qing Xunhua subprefecture, however, presents an alternate, paradoxical picture: Monasteries such as Labrang might have been growing in terms of wealth, numbers of buildings and monks, and properties, estates, and subjects, but this growth was accompanied by frequent litigation in Qing legal forums and a concomitant imbrication of Qing civil and military officials and their subordinates in the affairs of the monasteries and neighboring lay communities.

What were the ramifications of Tibetans' pursuit of justice in the context of Qing colonial administration? In the following essay, I will examine a particularly well-documented incident - the "White Slope Case" (baitupo an) of 1889 - in order to make two observations about the history of litigation in Xunhua subprefecture: First, this litigation led to the creation of a unique body of Qing jurispractices - a term I will elaborate on shortly - and second, it profoundly shaped the property and political relations of Tibetan communities, both lay and monastic, often leading to the legal inscription of pious activities. By "legal inscription," I refer to the reification, codification, and/or rewriting of religious observances and obligations by both indigenous elites and representatives of the Qing state. As a result of this legalizing process, indigenous people themselves observed that opportunities for personal or community discretion in religious matters narrowed and relations with local religious leaders and institutions became more binding and restrictive.

By the term "jurispractice," I mean to indicate a living body of legal procedures and precedents that were informed by several distinctive strands of jurisprudence. ${ }^{10}$ Qing officials, Geluk monks, and various laypeople argued for their positions on the basis of distinctive legal principles, but the resultant body of legal decisions - and the processes by which they were reached-

8. See for instance, Brag dgon pa dkon mchog bstan pa rab rgyas's comprehensive Tibetan-language gazetteer of Labrang Monastery and the Amdo region, the Mdo smad chos 'byung; and the biography of the fourth Jamyang Zhepa by 'Jig med phrin las rgya mtsho, Zhva ser ring lugs pa skal bzang thub bstan dbang phyug gi rtogs pa brjod pa rinchen phreng ba.

9. Nietupski 2011: 141-43; and Pirie 2006: 80-1.

10. For the original usage of the term "jurispractice" see, Hermes 2008: 33-34. My usage of "jurispractice" contrasts with Hermes, who defines jurispractice as a shared set of legal concepts or "legal mentalité" that on a whole does not add up to a "philosophy of law." 
were contingent and improvised combinations of these legal principles. The distinction between jurisprudence and jurispractice permits us to discuss practices of mediation, investigation, adjudication, and punishment separately from high, literary traditions of legal philosophy as articulated by monastic authorities in historical chronicles or Qing officials in magistrates' handbooks. Jurisprudence and jurispractice distinguish ways of speaking about the law from historically documented ways of acting legally.

\section{Xunhua Subprefecture as a Qing-Centered Pluralistic Legal Order}

Prior to the imposition of Qing control in the 1720s, legal authority in Amdo was distributed in multiple centers. The Khoshud rulers of the region utilized local versions of the Mongol-Oirat code of 1640 and employed secretaries and other subordinate officers to oversee its use. ${ }^{11}$ Monastic authoritieshierarchs of the Gelukpa and other schools of Tibetan Buddhism, possessed their own monastic charters (Tib. bca' yig) for managing the affairs of the their lay and clerical subjects, but also competed with the Mongol princes and other lay leaders for judicial authority. ${ }^{12}$ Wangchen Kyab, secretary to the sixthgeneration junwang ${ }^{13}$ Trashi Wanggyel (r. 1833-1850) and author of a historical chronicle of the Khoshud nobility described the tensions that emerged between Labrang and the Mongol princes as their subjects fled to Labrang when they perceived that its rulers were less likely to enforce capital punishment for serious crimes. ${ }^{14}$ Labrang-based authors such as Belmang Pandita Könchok Gyeltsen (1764-1863) composed polemical texts criticizing governance in

11. Güüshi Khan, ruler of Kökenuur, Kham, and Central Tibet participated in drafting the code. $C f$. Atwood 2004: 389; and Sneath 2007: 181-182.

12. On monastic charters, see Sullivan 2016.

13. Junwang: a Mongol prince of the second rank. For the first three generations after Qing incorporation, the leading Mongol prince of south of the Yellow River had held the title of qinwang (Mongol prince of the first rank). After the third qinwang died without heirs in 1770, the Qing court recognized the kinsman who succeeded him as only a junwang. Successive princes in southern Kökenuur held this title until the end of the dynasty in 1911. See appendix to Xiangzha Gabuzang, 280-281.

14. Dbang chen skyabs [Wangchen Kyab] 1848: 335, 356. This book exists only in manuscript form. The original text, dating to 1848 , was destroyed during the Cultural Revolution, but a local trülku, Shingza Kelzang had copied the text onto paper slips tucked into his roof and reassembled the book in 1973. Unfortunately a great deal of modern vocabulary slipped into the reconstructed text. See Oidtmann 2014: 268. 
the Mongol domains. According to Belmang, the exclusive observance of Gelukpa notions of Buddhist jurisprudence was a prerequisite for Mongol rulers who wished to enter into a formal "preceptor-donor" (Tib. mchod yon, also "priest-patron") relationship with the Gelukpa. ${ }^{15}$ Although both Belmang and Wangchen Kyab were writing in the early 19th century, it is probably safe to assume that these tensions over jurisdiction and jurisprudence had arisen from the moment when Mongol rulers committed themselves to a preceptordonor relationship with Gelukpa hierarchs and invited them into their domains during the 16th century. For people who lived in proximity to the Ming and early Qing-period frontiers of Shaanxi (and then subsequently Gansu province in 1666) or who traded in border markets, it is conceivable that Ming and Qing magistrates and sub-officials also served as potential legal forums. ${ }^{16}$

Between the mid-18th century and the late 19th century, the legal culture of the Amdo region gradually shifted from a multi-centric legal order to a statecentered legal regime in which imperially sanctioned codes and judgments rendered by imperial magistrates had the final word in local conflicts - or at least officials and litigants expected this to be so. In practice, however, official decisions were ignored, brought to alternate jurisdictions or levels of the Qing bureaucracy, purposely misinterpreted, retranslated, and frequently relitigated-often over decades. This extensive legal wrangling is what Lauren Benton, in her comparative study of law in colonial societies has referred to as "legal politics," or "the experience of strategic engagement with the law." 17 Moreover, as in British India, it was the contingent legal agitation by people at the margins of empire and not always the ambitions of metropolitan jurists or sovereigns that drove the centralization of the Qing colonial legal system. ${ }^{18}$

In the case of Amdo, the Qing court also played only a partial and often reluctant role in developing a state-centered legal order. The foundations of this legal order were laid during the reorganization of the Gansu borderlands following the defeat of the Mongol prince Lubsang-Danzin in 1723. Nian Gengyao and other Qing military commanders subsequently expressed

15. Oidtmann 2014: 315-327.

16. Yang \& Oidtmann 2015: 21-46.

17. Benton 2012: 1093 .

18. Benton 2002: 6-10, 24, 253. As a system designed to maintain the superiority of the Qing ruling house and its "metropolitan" Manchu, Mongol, and Hanjun banner elites and-in the mid to late 19th century, Han literati scholar-officials, as well as the distinctions and separations of subject populations-Han, Hui, Fan, etc. - the Qing imperial order in Gansu and Kökenuur approximated the colonial practices of contemporaneous European empires. For discussions of Qing "colonial” empire see Di Cosmo 1998, Hostetler 2001, and Perdue 1998 \& 2009. 
optimism that the former Tibetan subjects of the Mongol rulers could be transformed. Consequently, the dynasty attempted to separate Tibetan populations from their former Mongol rulers and subject them to the oversight of local officials from the routine provincial administration of the interior. In 1726, acting on the advice of Danai who had recently "exited the border" (chu kou) and conducted surveys of "Fan" populations south of Xining and west of Hezhou, the Yongzheng emperor (r. 1722-1735) approved the establishment of a "subprefect for pacifying the Fan" (Fufan tongzhi) to be based in Hezhou. ${ }^{19}$ The primary responsibility of the office was the collection of taxes from Tibetan communities across the border. For officials in Hezhou, this task would have been familiar because assistant prefects (tongpan) and subprefects (from 1604) had been responsible for collecting taxes from Fan communities located within the borders of Hezhou since at least the early 1600s and perhaps earlier as a result of their supervision of the Ming-era tea and horse trade. Thirty-six years later, in 1762, the office of the "Xunhua subprefect" was established when, in order to facilitate tax collection and closer oversight of Tibetan affairs, the subprefect was moved across the mountainous western border of Hezhou, to the fortified military outpost of Xunhua. Subsequently, the boundaries of Gansu were understood as having rolled westward and the province was seen as straddling the old divide between "inner and outer." 20 The appointment of a Hezhou subprefect was a model for the establishment of subprefects in Bayanrong'ge (1744), Taozhou (1748), Guide (1792), and Danga'er (1829).

The idea that the "Fan" would make extensive use of the new subprefect as a legal authority was clearly an afterthought. That it was not until 1733 that the Qing court began to consider how to deal with crimes involving the new non-Han subjects of Gansu suggests the question had been forced by the actions of local people themselves, who were beginning to test Qing officials as potential legal forums. Deliberations over legal procedures also reveal the optimism of some Yongzheng-era officials that the process of assimilating Fan populations into the empire would be smooth and quick. When he initially approved the Fan Statutes, the Yongzheng emperor only authorized them for a five-year period, after which they would automatically be replaced with the law code of the interior. ${ }^{21}$

Much like other colonial powers encountering unfamiliar cultural terrain, the attempt to produce a standard Fan law for the reference of Qing magistrates

19. Gong 1981 [1792]: 26.

20. As late as 1898, the Qinghai amban referred to Gansu as being both "inside and outside the passes (Gansu guan neiwai ji Qinghai)" (QSDG (GX 24/04/03), 7-YJ-130).

21. Xining Qinghai fanyi cheng li 1994 [1809]: 379. 
was a creative process. ${ }^{22}$ In 1808 , the Jiaqing emperor learned from Wenfu that the original Fan Code had been extracted from the existing Mongol statutes (Menggu li), not a preexisting Tibetan legal tradition. The court was also reminded that prior to 1733, Qing officials had already developed "statutes for Fan people (Fanzi lïli)" for Tibetans in Yushu and Nakchu that were also based on Mongol laws. ${ }^{23}$ That Qing local officials should reach for Mongol statutes is not unexpected. Danai had dismissed any possibility that the Tibetans themselves already possessed a distinctive system of jurisprudence. He informed the emperor that, "The Fan people are foolish and know nothing of legal systems." ${ }^{24}$ Moreover, since Mongol rulers had dominated the region from the late 15th century until the first year of the Yongzheng reign, it is only natural that the Qing would turn to the administrative traditions of Güiushi Khan and his descendants. ${ }^{25}$ Ortai and Yongzheng left the final form of laws and their promulgation up to Martai, a Manchu bannerman who had served in Qinghai with Danai since 1732 and was reported to possess experience with Tibetan regions. He was ordered to make sure that the laws were appropriate for Tibetans. ${ }^{26}$ It is probable that this order resulted in consultations with Tibetan and Mongol lay and monastic elites. The following year (1734), the Yongzheng emperor approved modifications to the Mongol statutes to accommodate the differences they perceived between Mongols and Tibetans. For instance, compensation standards were altered to account for the different relative rankings of Fan headmen and also in recognition of the belief that "Fan typically raise few horses but many yaks." ${ }^{27}$ After these changes had been made, the sixty-eight statutes of the code were translated into Tibetan (literally, "Tangut script," Tanggute zi).

Yongzheng and his field officers would have been surprised to learn that the Fan statutes were still the underlying framework for dealing with Tibetan conflicts 180 years later when the last Qing emperor abdicated. Zhou Xiwu, a Gansu literatus who traveled to Yushu in 1914 reported that a Tibetan translation of the Fan statutes was still in circulation. ${ }^{28}$ Although conceptualized as a

22. The classic case is the fabrication of a "traditional" Hindu legal tradition in Britishruled India. See Cohn (1996): 57-75; $c f$. Benton 2002: 128. See also, Morrison 2015: 127-149.

23. Xining Qinghai fanyi cheng li: 381.

24. Danai, quoted in Xining Qinghai fanyi cheng li: 381.

25. Qing administration in Xinjiang would also rely heavily on Mongol precedents. See Brophy 2013: 231-258.

26. Xining Qinghai fanyi cheng li: 381.

27. Ibid.

28. Zhou 1986: 117. 
privilege - not a right, once granted it proved difficult to retract. The Qianlong emperor granted extensions in 1736, 1740, and 1743. Finally, in 1748, the emperor declared:

The Fan subjects live in a faraway and desolate place and have their own customs. Therefore, since they are not familiar with all of our Code, it is not convenient to subject them to the laws of the interior in their entirety. If one cannot let the Fan govern themselves, at least one must compromise with their foreign dispositions. Later, if there are cases of murder or raiding, resolve the cases by fining them according to the Fan statutes. It is not necessary to request further extensions. ${ }^{29}$

Moreover, from the perspective of the Qing court, not only had the laws achieved a semi-permanent status, but also the purview of the code had expanded from the "Fan territories attached to the interior" to the entire jurisdiction of the Qinghai amban. ${ }^{30}$ In both Wenfu's memorial and the Jiaqing emperor's edict of 1809 sanctioning the continued use of the code, it was stated that the laws applied to Mongols as well as Tibetans. ${ }^{31}$ Wenfu argued to the court that in the event of rebellion or other large-scale violence that threatened the overall security of the frontier, the court should reserve the right to execute the instigators. However, he warned that experience had proven that introducing capital punishment for localized violence-murder or raiding, would only lead to a prolonged cycle of vengeful feuding. The cycle of revenge could be broken if Qing officials helped broker compensation between the concerned parties in accordance with the Fan statutes. ${ }^{32}$ In summary, the production of imperially sanctioned "Fan statutes" had the unforeseen effect of carving out an enduring and legitimate space for Tibetan law within the Qing empire. But what did this mean in practice?

29. Xining Qinghai fanyi cheng li: 379-380.

30. "Qinghai amban," alternately "Xining amban" or (Ch.) Xining banshi dachen: since 1725 the Qing emperors' resident minister in Xining who oversaw the affairs of the twenty-nine Mongol banners of Qinghai and the Fan of the Gansu borderlands.

31. Ibid.

32. Ibid. 


\section{Colonial Legal Culture in Xunhua Subprefecture}

I have yet to locate an explicit reference to the Fan statutes of either 1734 or 1809 in an eighteenth or nineteenth century Tibetan-language text. ${ }^{33}$ Archival sources from Xunhua, however, reveal that Tibetans, both individually and as representatives of their villages, nomadic communities, or monasteries, consistently requested that the conflicts be handled according to the Fan statutes and regulations. Although Qing officials generally felt obliged to state that their decisions were guided by these statutes, few decisions directly cite the code's sixty-eight regulations, primarily because they did not cover the religious activities of lamas or the complicated property arrangements of monastic estates and their subordinate lay communities. The importance of the Fan statutes lay not in their practical utility, but rather in their discursive utility. By agreeing to observe the "Fan statutes," subprefects were signaling a willingness to adjudicate in terms suitable to the disputants. Adjudication according to these alternate statutes meant not using the Qing Code-or in local terms, the laws of "China" (Tib. Rgya nag). It meant that the final decision would not only be grounded on locally accepted arguments and principles but also reached through a locally accepted process.

Demands for the Fan statutes were often couched in pleas for Qing officials to "take charge (zuozhu)" and assert the dynasty's authority over the region. Such pleas were also implicitly (and sometimes explicitly) calls for the intervention of the Qing military garrison based in Hezhou. Imperial authority - often referred to as "royal law" (wang fa), therefore, was articulated through the vernacular of the Tibetan statutes. The call for the exercise of royal law, however, should not be confused with support for Qing rule. On the contrary (and much to the chagrin of Qing officials), Tibetans were making a calculated effort to manipulate the colonial administrative apparatus. In this respect, the shift to a Qing-centered legal order in the Amdo region resembled what occurred in Bengal and Turkestan where the strategic use of the colonial institutions by indigenous people resulted in the centralization of judicial authority in a hierarchical structure. ${ }^{34}$ In Russian-controlled Turkestan, for instance, although a modified Islamic judiciary was left in place to handle

33. Neither Belmang's History nor Drakgönpa's Oceanic Book mentions these codes. It is possible that the codes are referenced in the biographies of the second, third, and fourth Jamyang Zhepas since all three of these monks were engaged in protracted legal conflicts that involved the Qing local officials. However, I have yet to come across such a reference in my readings of these sources.

34. For an account of these developments in Bengal, see Benton 2002: 131-37, 151-52. 
conflicts within Muslim communities, Russian authorities soon began to accept cases from dissatisfied litigants, leading to the creation of an appellate system. ${ }^{35}$ Following the conquest of Amdo in the 1720s, the Qing delegated judicial authority to local headmen, lamas, and Mongol banner aristocracy, yet soon found themselves constructing a hierarchical legal order when locals sought out Qing authorities to appeal the decisions of indigenous authorities or when conflicts entailed multiple communities and local jurisdictions. ${ }^{36}$

The role of Qing magistrates in the new subprefectures in Amdo most closely resembled that of the British East India Company "collectors" who presided over the "country courts" in rural India following Warren Hastings' reforms of the 1770s. The subprefect and the collector were simultaneously administrators and judges. The collector oversaw a civil court where cases could be heard according to either Hindu or Muslim law and specialists from these traditions were appointed to assist in adjudication. The British official also supervised a criminal court where cases were heard according to Muslim law. In Xunhua, the Qing subprefect was expected to adjudicate according to a variety of traditions of jurisprudence, including the Qing code and Tibetan and Islamic law (although the Qing state had not sanctioned any specific set of statutes or code to apply to Muslims resident in Xunhua). Unlike the officer of the East India Company, the Qing official did not distinguish between civil and criminal matters, nor did his many assistants have any formal standing within the Qing field administration on par with the Muslim and Hindu law officers of the British country courts. However, in both situations, as the embodiment of a pluralistic legal order, colonial officials were the object of intense legal politicking and ostensibly separate and distinct traditions of jurisprudence were in practice subjected to slippage and blurring.

As Cohn has argued, the British attempt to establish a Hindu legal order over the course of the 19th century resulted in the transplantation of English case law to India. While Qing authorities never consciously adopted a case law system, in practice cases - not codes, were central to the legal culture of Xunhua subprefecture. During the Guangxu reign (1875-1908), questions

35. Sartori 2014: 419-47, \& idem 2009: 401-34.

36. In the 1780s-1790s, Mongol nobility in Qinghai began petitioning the amban and the Qing court to handle cases of raiding. See Zhongguo diyi lishi dang'anguan Manwen lufu ("China First Historical Archives, Grand Council file copies of Manchu memorials”), 03-0189-2912-004 (QL 47/01/19, report from amban Liobooju); 030193-3282-003, 004 (QL 55/04/24, letter from Cagan Nomunhan \& reports from amban Kuišu); and 03-0194-3343-023 (QL 56/06/28, letter from junwang Naqan-Darji \& Kuišu). Labrang brought its first legal case to the Xunhua subprefect in 1772 (Gong 1981: 253-5). 
about the rightful scope of the estate of the Jamyang Zhepa and other reincarnate lamas (trülku) was an almost continuous focus of legal wrangling in Xunhua subprefecture. Although petitioners requested that the Qing authorities observe the Fan statutes, these codes appear to have only loosely informed the final outcome. Instead, litigation resulted in "decisions" (duan or fenfu) or oaths, accords, or community charters (ganjie, jieguo, xiangyue). By the late 19th century, these charters and decisions were agglomerated into a unified body of mutually recognized Qing jurispractices. These decisions and accords were translated into Tibetan (and occasionally Mongol) and stored in multiple sites - the subprefectural yamen, monastic archives, and the manors of headmen and women and Mongol nobility. Although they never resulted in new imperially sanctioned codes or in a revision of the existing statutes, these jurispractices were understood locally as having a rightful bearing on present community arrangements but could also serve as templates for resolving unrelated or indirectly related conflicts.

The following examination of the White Slope case of 1889 provides a welldocumented example of Qing jurispractices and the creation of an adjudicated accord (duanjie) that became a reference point for further litigation. Documents generated by the case also reveal the degree to which indigenous people and Qing authorities increasingly viewed the residents of Xunhua and neighboring districts as divided between two monastic domains - those of Labrang and Rongwo monasteries. Whereas just ten years earlier cases involving Tibetans from Xunhua or Mongols from Qinghai were handled without reference to the idea that the region was split between two grand confederations, in 1889, small feuds that began in places at some remove from Rongwo and Labrang were quickly understood by both petitioners and Qing officials as sparked by the machinations of these "Great Powers."

\section{The Growth of Monastic Confederations in Xunhua}

The development of two mutually hostile alliances of monasteries arose, at least partially, as a result of the controversy over the reincarnation of the first Jamyang Zhepa (1648-1721). Tensions appear to have emerged first between Labrang and the neighboring monasteries of Terlung (est. 1222, significantly expanded as Geluk monastery in 1558) and Tsö (est. 1682). The leadership of these two smaller monasteries and many of their affiliated lay communities had not supported the candidate ultimately identified as the second Jamyang Zhepa (1728-1791) and had resisted efforts by Labrang to supervise their 
activities. ${ }^{37}$ Litigation before Qing magistrates further shaped this schism. The second Jamyang Zhepa brought suit against Tsö in 1772 with the Xunhua subprefect. Eighteen years later (1790) and after six distinct stages of litigation, Qing authorities finally determined in favor of Tsö, preventing Labrang from appointing further abbots. The case established several precedents, most importantly that "each monastery should govern only itself" (ge guan ge si) and delimited new boundaries for Xunhua subprefecture: communities around Labrang - although not Labrang itself - were henceforth "taxpaying households of the interior" (neidi liangmin). ${ }^{38}$ Although the Qing court ultimately determined that Labrang was not a community directly supervised by the provincial administration-it was a "Mongol" monastery under the direct jurisdiction of the Mongol nobles and the indirect supervision of the Qinghai amban, by bringing their troubles to the attention of the subprefect and other officials, Labrang's monks had de facto placed their communityand any other future conflict with neighboring communities - firmly within the purview of the subprefect. A hierarchical appellate judicial structure was forming in the Xunhua area that straddled the Gansu-Qinghai border.

In 1807 the Qinghai amban Nayanceng delegated the governance of the "western Fan" - the Tibetans who resided in the western areas of Xunhua-to the Rongwo nangso, ${ }^{39}$ and in 1846 provincial officials placed Tsö formally under the supervision of Rongwo. ${ }^{40}$ In 1875 , following several years of violent conflict and litigation among communities to the north and east of Labrang, governor-general Zuo Zongtang approved the appointment of the third Sétsang Lama Lozang Trashi Rabgyé (1814-1879) of Terlung monastery - a trülku and monastic community with a long history of opposition to Labrang - to the position of "general administrator" (zongguan) of these communities. ${ }^{41}$ Subsequent Qing officials saw this move as an attempt to create a clear administrative hierarchy in an area that had been claimed by a number of competing lamas and lay headmen and counterbalance the growth of Labrang monastery, yet the death of the Sétsang lama shortly thereafter and subsequent legal battles over the jurisdiction of the lama's estate (both in terms of religious and temporal authority), stymied this policy. By the late 1880s,

37. Brag dgon pa dkon mchog bstan pa rab rgyas 1987 [1865]: 555-556.

38. Gong 1981: 253-55.

39. Song 1997: 68. "Nangso" (Tib. nang so, Ch. angsuo) was the title for the hereditary lay rulers of the lay communities associated with Rongwo monastery. The other Tibetans of Xunhua were referred to as the "southern Fan."

40. QSDG (GX 17/10/03) 7-YJ-2985.

41. Zuo 1979: vol. 4, 1884-1885. 
local and imperial authorities alike shared the conviction that all the Tibetan communities in Xunhua were affiliated with either the Jamyang Zhepa of Labrang or the Shartsang Lama of Rongwo monastery. While in the 1870s, the principle that, "each monastery should govern only itself" seems to have enabled smaller monasteries and lay communities to retain ties to a variety of different monasteries, in the 1880s-90s, the phrase was consistently interpreted as "each monastery shall govern its own monasteries." 42

Locals and colonial officials shared the conviction that all communities in Xunhua belonged either to Labrang or Rongwo. According to the Rongwo headman, the notion that monasteries, monks, and lay communities could exist somehow outside these two confederations was absurd. In a letter to the Xunhua subprefect in 1889, the Rongwo nangso wrote:

Labrang is no different from the royal [Qing] law (wang fa), it possesses its own jailers and indiscriminately detains Fan, Han and Hui. The fact that Fan from all over become his tax paying subjects and do his bidding is simply a matter of making vassals (shuantou) out of the poor and weak.

Everywhere [Labrang] goes it purchases commoners with cash. If there is no royal law, the poor and desperate will seek out his money and become his subjects. Your royal law not only does not govern him, but it is said that all his instruments of torture and coercion are permitted under the royal law! My Rongwo monastery is just like your Labrang. We also possess three thousand lamas and ourselves supervise numerous headmen. And just like your Labrang, I will also take matters into my own hands. ${ }^{43}$

Couched in sarcastic derision of the Qing and the usurpation of imperial prerogatives by Labrang, the Rongwo nangso hereby warned the subprefect that in the absence of royal law, the region was fast being carved into two opposing camps. Some of the subordinates of the Repgong nangso, in a separate petition, described local affairs in starker terms: "For us Fan, it's just dog-eat-dog - we don't understand the underlying principles and can only beg for Your Honor's mercy." ${ }^{44}$ Tensions between monastic confederations led to heightened scrutiny of the legal status of both reincarnate monks and lay communities.

42. For a detailed account of these developments, see Oidtmann 2014: 458-525.

43. QSDG (GX 15/08/29), 7-YJ-4535.

44. QSDG (GX 09), 7-YJ-2729: “xiaodemen shi Fanzi, gou yao gou de, bu dong lixing li, qiu she'en li!" 
This heightened concern with identifying clear and exclusive lines of authority between subjects and rulers of monastic domains is marked in the archival record by the emergence of a new term to describe this relationship, shuantou. This term is most likely a translation of the Tibetan verb mgo btags ("to capitulate") and is unique to the legal discourse of Xunhua subprefecture beginning in the late 1880s. It functions as both noun and verb, meaning, respectively "vassalage" (as in "shuantou guanxi") and "to make a vassal." It also has profoundly negative connotations. In most usages, to shuantou is to illegally subjugate individuals and communities for nefarious purposes. In the context of identifying and disputing the status of vassals, acts such as pilgrimage and almsgiving, participating in festivals, studying at neighboring monasteries and bonds of discipleship, were scanned for signs of shuantou. It was precisely in this legal reification of religious activities and relationships that the litigation and violence of 1889 originated.

\section{The White Slope Accord of 1889: Qing Frontier Jurispractices in Action}

According to the Terlung general administrator, who at the time was the manager (Tib. gnyer les pa, Ch. nieliwa) of the Sétsang lama's estate, ${ }^{45}$ the trouble began with the honpo ("headman," Tib. dpon po, Ch. hongbu) of the hamlet of Dangang and the manager of the estate of another prominent local lama, the Gyangro trülku of Khagya monastery. ${ }^{46}$ The zongguan claimed that the Dangang community belonged to Terlung and that the headman and Gyangro manager had been bribed to shuantou his community to the Jamyang Zhepa. When the Dangang headman's uncle refused to go along with the scheme he was murdered. ${ }^{47}$ Investigators confirmed parts of this story and added further details:

According to the report of the xiejia Mama'erli: 'The Khagya manager greedily accepted bribes from Labrang and mischievously persuaded the headman of Qiexiantan to lead his subjects to submit to Labrang. He also convinced the woman

45. The fourth generation Sétsang lama had just recently passed away at the age of eight a year earlier.

46. In the archival documents, "Dangang" alternately refers to the hamlet of which the honpo was in charge or is used as the personal name of the honpo. The Gyangro lama had a history of friendly relations with Labrang.

47. QSDG (GX 15), 7-YJ-2679. 
headman of Wangga'tan to submit half of her subjects to Labrang. This resulted in Terlung mobilizing its troops and killing the Qiexiantan headman Dangang, torching his home, burning to death his wife and a maid. At this, the Gyangro manager called up troops from Labrang and led them through Terlung to [Namlha] where they killed one commoner and burned several homes. Terlung was enraged and planned on attacking both Qiexiantan and the female headman in Wangga'tan. However, I was able to convince Terlung to hold back.' ${ }^{48}$

Matters, however, quickly escalated and spread beyond upper and lower Namlha (Tib. Gnamlha, Ch. Labula), a string of agricultural villages located along the Sangchu River between Labrang and Terlung. The xiejia noted that the Gyangro manager had persuaded the Jamyang Zhepa to call up a "large military force" from its allies at Amchok, Mewo, Bora, and Khagya. ${ }^{49}$ Less than a month after the murder of Dangang on June 6,1889, military forces allied to Labrang launched an attack on Tsö that resulted in the destruction of several hamlets on June 28 and $29 .{ }^{50}$ Rongwo responded in kind. Forces from Terlung, Hortsang, and Rong' ar rushed to the defense of Tsö while Rongwo's militia launched a direct attack on Labrang, arriving during the night of July 14 (GX 15/06/17) ${ }^{51}$ As the Qinghai amban and the governor-general later wrote in a memorial to Beijing,

"From the 29th of the fifth month [June 27] through the latter half of the sixth month [July], the Southern and Western Fan from near and far engaged in a spree of arson and murder along a three to four-hundred $l i$ front. The conflagration burned with an intensity that proved nearly impossible to extinguish." ${ }_{22}$ The fighting ceased when official troops from the Hezhou garrison arrived at Labrang and Tsö and inserted themselves between the warring parties, thus buying time for negotiations. ${ }^{53}$

According to the Rongwo nangso, who frequently represented Terlung and Tsö in subsequent litigation, the matter should have rested after the killing of Dangang. His death was justified in light of his attempt to shuantou his people

48. QSDG (GX 15/05/26), 7-YJ-2686. This information was reported by a Muslim xiejia employed by the Xunhua subprefect on a hereditary basis to collect taxes from Fan communities.

49. Ibid.

50. QSDG (GX 15/08/23), 7-YJ-4535.

51. QSDG (GX 15), 7-YJ-2678. The losses suffered by Labrang during the attack were substantial: QSDG (GX 15), 7-YJ-2681.

52. QSDG (GX 16/01), 7-YJ-2965.

53. QSDG (GX 15), 7-YJ-2684. 
to Labrang. Therefore, the matter was really an internal one: "Their killing one of their own men is a matter with which Labrang had no right to interfere." 54 The Rongwo nangso and the monks of Rongwo monastery portrayed the whole affair as stemming from the avarice of the Jamyang Zhepa: "That Jamyang Zhepa of Labrang may be a lama who knows his scriptures, but he isn't the lord of all places!" 55 In a separate letter to the governor-general they called for his arrest and punishment. ${ }^{56}$

The Dangang honpo's view of this matter was unfortunately silenced before it could enter the official record. The "headwoman" of Wangga'tan, Pöntsang Lumogya, however, along with "no small number of supporters," had escaped to Labrang and presented their case to the magistrates. ${ }^{57}$ Lumogya and her supporters filed at least three petitions with the committee of Qing officials delegated to adjudicate the dispute. She forcefully asserted the independence of her community from the Sétsang estate and the Terlung zongguan. Lumogya stated that she was descended from a continuous line of lay rulers and that if the community was to be considered subject to any monastery or trülku's estate, it would be to their own two monasteries and the A-qiong (or A-qun) trülku. Other than requesting prayers or divinations from the Sétsang lama, her people "had not become his vassals (shuantou)." 58 In one of the petitions, Lumogya and her co-petitioners wrote, "There has been only one honpo here and certainly none of your royal law! This manager [i.e. the zongguan] acts as if he is even more important than you officials! [His claims] are new roads [i.e. unprecedented]. According to the old rules, we've had successive generations of our own honpo and when the lay people had problems, it was our honpo who dealt with them. Terlung had nothing to do with it." ${ }^{59}$ Lumogya

54. QSDG (GX 15/08/23), 7-YJ-4755.

55. QSDG (GX 15), 7-YJ 4545.

56. QSDG (GX 15), 7-YJ-4542. For further petitions from the Rongwo-Terlung faction, see: QSDG (GX 15/07/10), 7-YJ-4544 (concerning Rongwo's justifications for use of military force against Labrang); QSDG (GX 15/08/17), 7-YJ-4534, (Rongwo nangso disparages the local Qing officials for inept handling of the case so far). For a petition from Tsö accusing the Qing officials of having double standards when it came to dealing with Labrang, see QSDG (GX 15/08/15), 7-YJ-4534.

57. QSDG (GX 15), 7-YJ-4503.

58. Her monasteries are identified alternately as the Guomang zhacang, Guola si, Nanlagongsesi, or Labula si. Interestingly, the A-qun lama cited by Lumogya himself submitted a statement to the Qing adjudicators arguing that he was in fact subordinate to Terlung. See: QSDG (GX 15/07/18), 7-YJ-2679.

59. QSDG (GX 15/09/02), 7-YJ-4544. 
concluded her deposition by clarifying the nature of her relationship to Labrang and Rongwo:

According to the historical statutes, Rongwo has no authority over any matter large or small, as these matters are the prerogative of the headmen. Monasteries are just monasteries. They are places we travel to worship, offer tea, and recite sutras. This is not my first time to make a pilgrimage to Labrang. How can you tell me that prostrating before the Buddha is a bad thing? I have been coming to the monastery to worship the Buddha and make offerings for many years, along with all those other Tibetans ${ }^{60}$ who consider Lhasa, Kumbum and Labrang to be holy places of pilgrimage. This is simply established custom. ${ }^{61}$

Representatives of the Sétsang lama's estates, she argued, had grossly misconstrued not only the nature of her community's relationship to the Sétsang lama, but also to Labrang and the Jamyang Zhepa. They currently resided at Labrang, she petitioned, because it had become unsafe to remain in their homes. She and her fellow petitioners hoped that "in your investigations, you Chinese officials (Han guan) can accurately understand the matter." ${ }_{2}$

The statements above are drawn largely from petitions (bing) collected by the Xunhua subprefect Cangyun (Manchu, served 1886-1894) and Zhang Shixi $^{63}$ after their arrival at Labrang in July (GX 15/06/04, 1889-7-1). In addition to the testimony of Lumogya and elders from her community, the two magistrates also met with the Jamyang Zhepa, the steward, and other members of the monastery's governing assembly. ${ }^{64}$ According to a subsequent report from Cangyun, the Jamyang Zhepa held a formal audience with the Qing officials at noon on July 2, in the main prayer hall of the monastery. The kūtuktu was seated on his primary throne while the Qing officials were arranged in rows to his left and right. The monk then produced several Tibetanlanguage documents written on yellow silk issued by successive Dalai Lamas and Changkya lamas during the Kangxi, Yongzheng, and Qianlong reigns. Of these, the subprefect noted that the second and third documents had been issued by the Changkya lama and recognized Labrang's control over Hortsang, Tsö,

60. Here the original petition reads zangmin, an unusually early usage of this term.

61. QSDG (GX 15), 7-YJ-4542.

62. Ibid.

63. Zhang was a magistrate-in-waiting (houbu zhixian), most likely employed on the staff of the governor-general in Lanzhou.

64. According to some reports, the Jamyang Zhepa was away traveling in Mongol territories when the violence began. 
Khagya, Terlung, parts of Bayanrong subprefecture (north of the Yellow River across from Xunhua), as well as "a large number of territories in Sichuan, Tibet, Taozhou, and Minzhou." Cangyun noted that these were the documents that had previously surfaced when the Qing adjudicated the Tsö-Labrang conflict in 1790: "These were items that had never been handed over when the former governor-general had requested that the Qinghai amban close the case. And that monastery has continuously considered them to be sacred objects." ${ }_{65}$ The Jamyang Zhepa also presented as evidence a decision issued by a Xunhua subprefect in 1777 during the course of the litigation from 1772 through 1790. This decision had supported Labrang's territorial claims, but had ultimately been reversed. Cangyun wrote that this document also "should have been handed over for annulment yet had not been." The Jamyang Zhepa provided one further Jiaqing-period (JQ 20,1815) certificate issued by the Xunhua subprefect and two local military officers stating that Terlung, Rong'ar, and Khagya all belonged to Labrang. However, Cangyun dismissed the document since it lacked official stamps:

With just a glance one can tell that it is inadmissible as evidence. However, [the Jamyang Zhepa] considers it a treasured possession and if I alone were to point out that it is nothing but waste paper, he would have become deeply embittered and it would have been impossible to set him at ease. Therefore I ordered my accompanying secretary to carefully transcribe each document and I have submitted them to you for further appraisal. ${ }^{66}$

Although the subprefect dismissed much of the evidence brought forth by Labrang, Cangyun's report reveals that the monastery did possess an archive of Qing documents and was prepared to muster them in defense of its claims. Moreover, Cangyun noted that the Jamyang Zhepa would accept Qing adjudication. ${ }^{67}$ Labrang ultimately did submit several petitions stating its claim to Tsö and other contested territories that have been preserved in the archival record. ${ }^{68}$

65. QSDG (GX 15), 7-YJ-2678. It is possible that the Jamyang Zhepa also submitted a written attestation of these claims at this time. See: QSDG (GX 15), 7-YJ-4643. The Jamyang Zhepa stated, “ This year, since it was determined that [the people of] Tsö were still my tribes, I punished them."

66. QSDG (GX 15), 7-YJ-2678.

67. Ibid.

68. Ibid. In this document the petitioners from Labrang cite several Qing decisions (QL 37,42 ) as evidence of prior Qing sanction of their claims. With regards to the Jiaqingera decision to pass the supervision of Tsö to Rongwo, they write: "During the Jiaqing 
Perhaps because the subprefecture's archives had been lost to fire in 1864 when Muslim rebels occupied Xunhua, for Cangyun and Zhang Shixi, the authoritative record was Gong Jinghan's Xипhua Gazetteer of $1791 .^{69}$ They brought the gazetteer with them during the investigation and upon arrival at Labrang read aloud the pertinent sections of the gazetteer to an assembly of monks. According to Cangyun, the gazetter had an edifying effect. Upon hearing the gazetteer, "the anger was drained from their hearts and, as they subsequently understood the [true] facts of this matter, they were no longer willing to engage in violence." 70

Yet, as Cangyun himself admitted in a memorandum for fellow officials concerning the resolution of the case, the nature of Xunhua subprefecture's jurisdiction over Labrang was not clearly stated. Gong Jinghan's account of the Qianlong-period litigation between Tsö and Labrang had concluded with the ambiguous formulation that, "Labrang is within the territory of the subprefecture but not under the control of the subprefect" (zai tingdi er fei ting suoshu). The reason given in the gazetteer was that Labrang was a "Mongol" monastery and thus under the supervision of the Mongol prince in neighboring Qinghai. ${ }^{71}$ Cangyun wrote, "According to the gazetteer, during the Qianlong reign it is said that each served itself. Therefore I do not know when it entered the registry (i.e. jurisdiction) of the subprefecture, nor are there any cases that I can check." ${ }^{72}$ Still, neither Cangyun nor his colleague Zhang doubted the legitimacy of their presence at the monastery. In a separate report to superiors, Zhang wrote that the arrival of the subprefect calmed an extremely tense situation. "The monks of Labrang," he noted, "all felt that the Jamyang Zhepa had not handled things well, but in order to spare his feelings, spoke up for him and helped him explain the situation." In fact, Zhang concluded that there were many in the monastery who wished that a Qing official would reside permanently at the monastery, as a "protective talisman." 73

reign the four valleys of Tsö again changed their allegiance, this time going to Rongwo in Bao'an. After this official troops again arrived and after learning of [Tsö's] error determined that they should again become a tribe subordinate to Labrang... This matter is on record with the officials [i.e., the Qing government at Xunhua]. After many years of not looking into this matter carefully, I recently discovered that Tsö was still one of my subordinate tribes, so I attacked Tsö."

69. QSDG (GX 15), 7-YJ-2684.

70. QSDG (GX 15/07/08), 7-YJ-2678.

71. Gong 1981: 255.

72. QSDG (15/06/10), 7-YJ-2681.

73. QSDG (GX 15/07/08), 7-YJ-2678. 
The gazetteer's account of Labrang monastery, the Jamyang Zhepa, and the history of their conflict with Tsö monastery strongly influenced deliberations among Qing officials as they weighed their options for handling the conflict of 1889. In his letters from Labrang, Cangyun advised against recognizing Labrang's claim to Tsö and reversing what he understood from the gazetteer as a policy of "restraining the Jamyang Zhepa." 74 However, he also informed his superiors that the situation in Xunhua was fundamentally different from the 1790s. Whereas during the early 19th century Labrang "relied on the power of the [Mongol] prince to vie with the Fan for territory," seventy years later, "the monastery has expanded to over sixty temples inhabited by numerous Fan and Mongol [lamas] and their entourages. Its prestige and power ever increase and it bursts with prosperity. In its struggle for Fan territory it continues to broaden its reach and its avarice is insatiable." ${ }^{\prime 7}$ For Cangyun, Labrang was no longer simply a "Mongol" monastery administered and potentially restrained by the Khoshud princes. "Originally a Mongol monastery, now that the Mongols have weakened, the monastery grows stronger by the day." 76

This transformation posed a thorny administrative problem: the Mongol nobility could no longer be expected to control the monastery, but it was still distinct from the "tax-paying Fan" administered by the Xunhua subprefect. Moreover, the gazetteer offered no easy answers for how to adjudicate the current dispute over communities located in the valleys between Labrang, Terlung, Tsö, and Rongwo. In a private letter, Cangyun, speaking on behalf of the committee delegated with resolving the case, weighed the dilemma for the governor-general, writing that approving Labrang's claims to communities in Khagya, Gyangro, and upper and lower Namlha would earn Labrang's compliance, but "would not only mean discarding the license granted by the previous governor-general [i.e. the 1875 license granted by Zuo Zongtang to the Sétsang zongguan] as waste paper but would make it difficult for Tsö and Terlung to survive - an outcome Rongwo would not abide." ${ }^{77}$ Moreover, Cangyun warned that they must avoid reproducing decisions that oversimplified matters by granting whole districts to one side or the other. Any solution, Cangyun suggested, could only involve painstaking consultation with the "taxcollecting xiejia and villagers" who were familiar with "who governed each small place." 78 The magistrate was thus proposing a detailed survey of local

74. QSDG (15/06/10), 7-YJ-2681.

75. QSDG (GX 15), 7-YJ-2684.

76. QSDG (15/06/10), 7-YJ-2681.

77. QSDG (GX 15), 7-YJ-2684.

78. Ibid. 
Tibetan communities in order to assess their status relative to the two large confederations. This only exacerbated the pressure on rural religious activities, as each "little place" (xiao diming) was called on to enshrine its allegiances in binding public legal documents.

\section{The Final Settlement}

The committee of Qing officials brokered a final settlement between Labrang and the Rongwo-led alliance on October 10, 1889 at a location quite removed from Xunhua town in the grasslands between Labrang, Rongwo, and Terlung. ${ }^{79}$ In private communications with provincial authorities, the committee wrote that it "decided the case according to the old cases from 1790 , 1846, and 1875" and rejected the petitions brought by Labrang. Although the committee faulted Terlung officials for their murder of the Dangang honpo, they directed their censure at the Jamyang Zhepa: "The Jamyang Zhepa of Labrang on the basis of a hundred years of worthless evidence sought to gobble up Tsö and recently colluded several times with Fan headmen from tribes subject to Terlung to establish relations of vassalage. They hoped to alter the statutes fixed by the decision of 1875 . This created jealously and animosity between the Fan and chiliarchs and managers of Terlung." ${ }^{80}$ The actual terms of the accord, however, were much more complex and offered a complete victory to neither Labrang nor Terlung monastery. A copy of the accord appears to have survived in the Xunhua archives only in a fragmentary form. The extant articles addressed the following issues:

1. Punishment of the manager of Terlung monastery for the murder of the Dangang honpo and the future governance of the headman's former subjects.

2. Release of the son of the murdered uncle of Dangang honpo by the Dangang household where he had been held hostage.

3. Administrative and religious arrangements for the hamlet of Upper Namlha.

4. Administrative and religious arrangements for Lower Namlha and the headwoman Lumogyua. ${ }^{81}$

79. The case then came to be referred to by a nearby geological feature, the tall white cliffs that border the Genkya grasslands.

80. QSDG (GX 15) 7-YJ-2678. For a full translation, see Oidtmann 2014: 493-4.

81. QSDG (GX 15), 7-YJ-4723. 
The following two extant articles concerned restitution between the various parties for loss of life, injuries, and physical damage to homes, religious structures, and crops according to "Fan custom (Fan su)." These latter articles were most directly influenced by the Fan statutes. On the basis of subsequent petitions from relevant parties such as Hortsang, Terlung, and Labrang reporting the exchange of reparations, one can assume that the missing articles laid out a fairly detailed list of obligations and a formal schedule by which they had to be completed.$^{82}$ Furthermore, in a jointly submitted memorial to the court in Beijing, the governor-general and the Qinghai amban reported that the accord stipulated that the managers of the concerned monasteries, including Terlung and Khagya, were to be replaced and not permitted to serve again. ${ }^{83}$

The terms of the agreement are significant in several respects. To begin with, despite a rhetorical posture of overall hostility to Labrang and other petitioners harbored by the Jamyang Zhepa, the final accord did not grant Terlung monastery blanket authority to the contested region in the same way as Zuo Zongtang's 1875 decision. The descendants of the Dangang honpo, for instance, owed no further financial obligation to the Terlung Monastery and were promised a degree of political independence from Terlung once the son of the Dangang honpo reached maturity. In the third article, the committee members also reduced the political authority of Terlung monastery by formally recognizing Labrang's claim to estates in Upper Namlha. Moreover, the officials moved to place those Tibetans of this locale who were not tenants of reincarnate lamas under the direct authority of Xunhua. In this respect, the accord marked a significant innovation over previous policies as the Qing officials now distinguished "commoner (baixing)" from "tenant (dianhu)." According to article three, revenue from commoner households would henceforth no longer be divided between authorities in Terlung and Xunhua. In effect, the dynasty was now claiming direct ownership of these "commoner" households and creating "imperial colonies" in the midst of other communities indirectly governed for the Qing by Terlung monastery and the Sétsang general administrator.

The status of Tibetans subordinate to Rongwo and Terlung as "grain tax Fan (liang Fan)" was not new. According to the Xunhua Gazetteer, the classification of Tibetans from Tsö, Khagya, and Rongwo as tax-paying commoners was cited as the primary reason behind the 1790 decision to rule against Labrang's

82. The following document, for instance, reports the payment of reparations to Labrang by subordinates of Hortsang and Tsö: QSDG (GX 15/10), 7-YJ-2683.

83. QSDG (GX 16/01) 7-YJ-2965. 
wish to appoint an abbot at Tsö. ${ }^{84}$ In 1889 , the anti-Labrang faction adopted this principle as a key argument in their appeal for Qing intervention. For instance, in a petition to the Xunhua subprefect, three lamas from Hortsang (a district ostensibly under the jurisdiction of the Sétsang zongguan) wrote that "Hortsang is not willing to become the subjects of the great trülku of Labrang. Instead we should be considered commoners of Xunhua subprefecture. The people of Hortsang contend that a man cannot serve two masters... If one were to compel us to submit to Labrang, our opposition would be so strong that it would be easier to kill us!" ${ }^{85}$ The petitioners' sentiment echoed the notion held by Qing officials that Labrang should not be permitted to make inroads in those communities they believed lay in the territory of Xunhua. Yet the establishment of specific communities as directly ruled "imperial colonies" (my term) was a novel outcome of the litigation process. In the early stages of litigation after first arriving at Labrang, Qing officials expressed no interest in establishing more direct rule over Tibetan communities in Upper Namlha. This solution may have presented itself as the only alternative to recognizing the claims of either Labrang or Terlung in their entirety. In the years after the White Slope Accord, Qing officials increasingly adopted this expedient solution when faced with quarrels over people and land in Xunhua. Moreover, Tibetan communities that felt threatened by Labrang themselves advocated for and achieved status as imperial colonies.

The 1889 accord also reveals an attempt by Qing officials to distinguish acts of piety such as alms-giving and pilgrimage from the obligations due from the tenants of the corporate estates of reincarnate lamas. Qing officials appreciated the degree to which the conflict between Labrang and its neighbors had been sparked by divergent interpretations of pilgrimage and donations to monastic estates in upper and lower Namlha. In other words, the accord aimed to disentangle religious acts from political relationships. Article three clarified, for instance, that residents of Upper Namlha had the right to travel unhindered to Labrang at regulated intervals and that such acts should not be confused with their political status vis-à-vis either the Qing state as subjects of the emperor or as tenants of various estates. Qing officials were similarly persuaded by Lumogya's protestations. While the fourth article did not formally recognize a right to make pilgrimages to Labrang, it did affirm that their flight to Labrang had been mistaken for an act of legal vassalage (shuantou). Article four not only recognized Lumogya's political authority but enhanced it by licensing her as a hundred-household head. Yet the nature of this authority was carefully

84. Gong 1981: 253.

85. QSDG (GX 15/06/06) 7-YJ-2681. 
parsed. Although her subjects did not become legal vassals of the manager of Terlung monastery like the other forty households of Lower Namlha, they were, however, still under the "general administration" of the Sétsang lama.

This complicated arrangement of nested authorities most likely reflected an attempt at reaching a compromise between Labrang and Terlung. The discursive finesse of article four conveyed a subtle distinction between the authority of the manager of the Sétsang Lama's estates at Terlung monastery and the authority that the Sétsang Lama derived from his appointment as zongguan within the colonial bureaucratic apparatus. On paper, Lumogya and her subordinate households were independent of Terlung. Unfortunately for Qing magistrates, subsequent petitions demonstrate that both partisans and opponents of Terlung saw little difference between the institution of the Sétsang zongguan and Terlung monastery. The Sétsang lama was the founder of the monastery and titular owner of its estates. Moreover, during the 1880s through 1890s, in the absence of an adult Sétsang reincarnation, monks from Terlung shouldered the responsibilities of the zongguan. The blurred boundaries between Sétsang lama and Terlung monastery and the ambiguous separation of administrative authority between the Sétsang zongguan and local headmen/women such as Lumogya proved an ongoing source of conflict and litigation.

In the White Slope case, Qing officials attempted to deliver peace by clarifying local relationships and inscribing them in imperially-sanctioned decisions. The process of crafting the accord entailed much closer scrutiny of local society than had occurred in 1875. Qing officials helped reify an increasingly complex matrix of authorities - Labrang, Terlung, lay headmen, and Qing officials. Within a single hamlet, residents could find themselves and their neighbors connected to very different hierarchies of authority, each of which had profound implications for everyday life both mundane and spiritual. Although it might be possible to interpret this process as an example of what James C. Scott has described as the desire of modernizing states to make society more "legible" and thus more readily governable, the above account of the White Slope case stresses the degree to which this process was driven from the bottom-up by local events and indigenous interests. ${ }^{86}$ Intractable inter-monastic feuds were the catalyst for the clarification of local political and religious relationships. The conflict and litigation process led to increased Qing involvement in Tibetan affairs, but for Qing officials this was not necessarily a welcome development. In brokering the White Slope accord, Qing officials wagered imperial prestige in an attempt to bring peace to the violent politics of the Gelukpa monasteries and their trülkus. Yet this bet did

86. Scott 1998 . 
not pay off. Just five months after the ink had dried on the White Slope accord, it became the focal point of renewed legal politicking when Tibetan elites took different interpretations of its key clauses. The imperial guarantee implicit in the agreement meant that the indigenous disputants immediately turned to Qing official forums for redress in the case. And since imperial prestige had been placed on the line, Qing officials were obliged to attempt to salvage the accord.

\section{Conclusion}

The White Slope case was but one of hundreds of legal cases in which Tibetans in Amdo encountered the Qing empire between 1872 and 1911. Although more significant than many of these other "Fan cases," it highlights the influence of the Qing colonial legal order on the boundaries of monasteries, monastic alliances, and the estates of reborn lamas, as well as on the nature of legal obligations and privileges for Tibetan villagers vis-à-vis neighboring religious institutions. It has been asserted that during the late Qing, Labrang monastery was a polity, "ruling an area about the size of Switzerland." ${ }^{87}$ This portrayal of Labrang as a large, unified and contiguous domain organized around the charisma of the Jamyang Zhepa is problematic in several respects. ${ }^{88}$ First, it should now be clear that several neighboring lay and monastic communities fiercely contested Labrang's control. The fourth Jamyang Zhepa, far from serving as a rallying point for Tibetan Buddhists around the region was the focus of ongoing calumniation from multiple quarters. Second, this characterization oversimplifies the layered and multivalent obligations held by many Tibetan households. Communities such as those led by monks at Rongwo or Terlung monasteries might have escaped the reach of the Jamyang Zhepa, but as a result of Qing intervention on their behalf, they gained tax obligations to the Qing state in addition to those owed to their own lay and clerical leaders. Finally, references to a "Fan" legal tradition in Xunhua entailed more than implementing a pre-existing "Fan" legal system. Instead, the "Fan laws" were a unique fabrication of the Qing period. Around the imperially-sanctioned idea of a timeless "Fan" criminal code, Qing officials and Tibetan litigants gradually built a scaffolding of accords, decisions, pledges and other precedents that formed the basis for an original set of distinctly Qing jurispractices. While

87. Schaeffer, Kapstein, \& Tuttle, eds. 2013: 601.

88. For such characterizations, see Nietupski 2011, \& Makley 2007: 39-40. 
monks like the Zhamyang Zhepas did retain their own judicial authority, they also participated in a legal order centered on the Xunhua subprefecture.

Far from being imposed from above, indigenous authorities actively sought out this legal regime and helped structure it through their legal agency. Their demands for the exercise of "royal law" resulted in the articulation of Qing authority through the seemingly familiar language of the "Fan statutes" and the decisions made on their basis. While calls for Qing officials to involve themselves in local legal conflicts should not be confused as statements approving the legitimacy of Qing rule, they nevertheless made the Qing officials and jurispractices a tangible part of daily life.

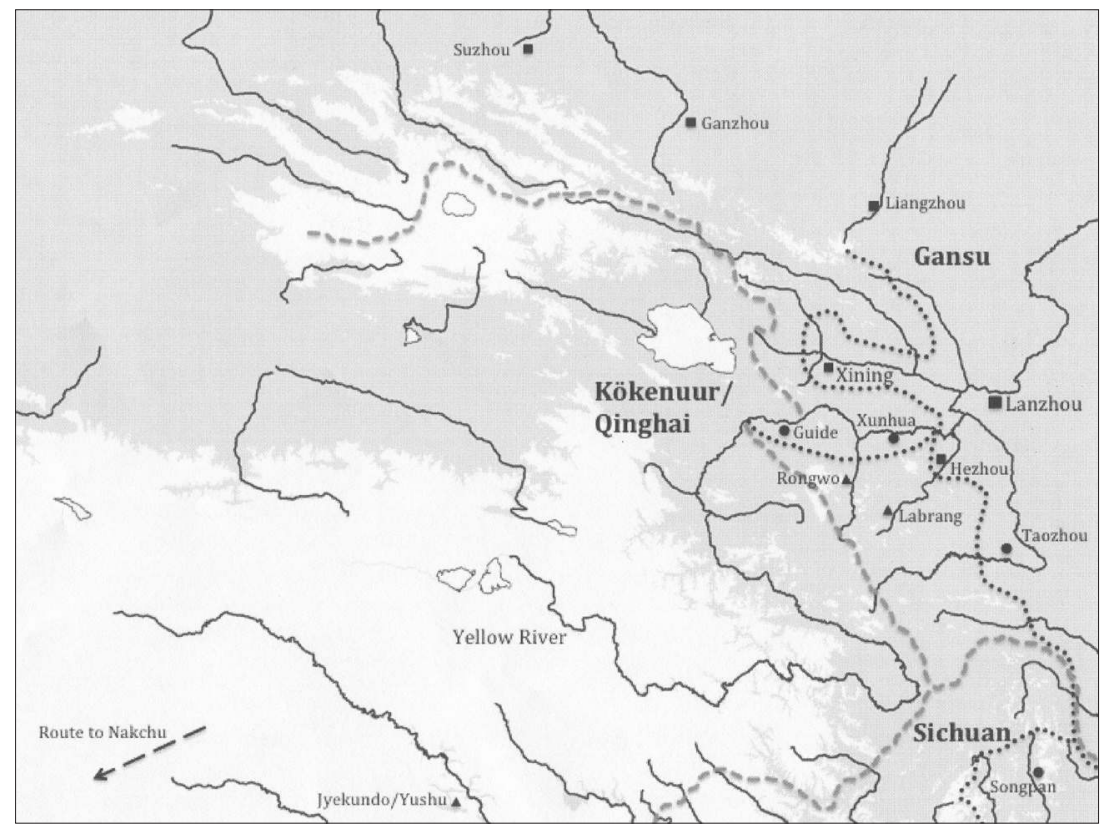

Figure 1. Overview of Gansu-Qinghai borderlands

Black circles and triangles represent, respectively, the subprefectures and Tibetan monasteries or communities most relevant to this article. The dotted black line approximates the southwest border of Gansu province according to the boundary markings on the Kangxi survey of 1717 (Huangyu Quanlantu: plate 4.4). The dotted line that swings below what would become Guide and Xunhua (the "Gui-Xun salient") exists on the original map and is of uncertain meaning, since no administrative centers or other settlements are indicated within this territory. Textual evidence discussed in this essay suggests that Qing officials in the 1720s saw the boundary as running from Xining past Hezhou, as indicated. The dashed gray line approximates the border of Gansu and Sichuan provinces according to the maps of the Guangxu Huidian of 1899. 


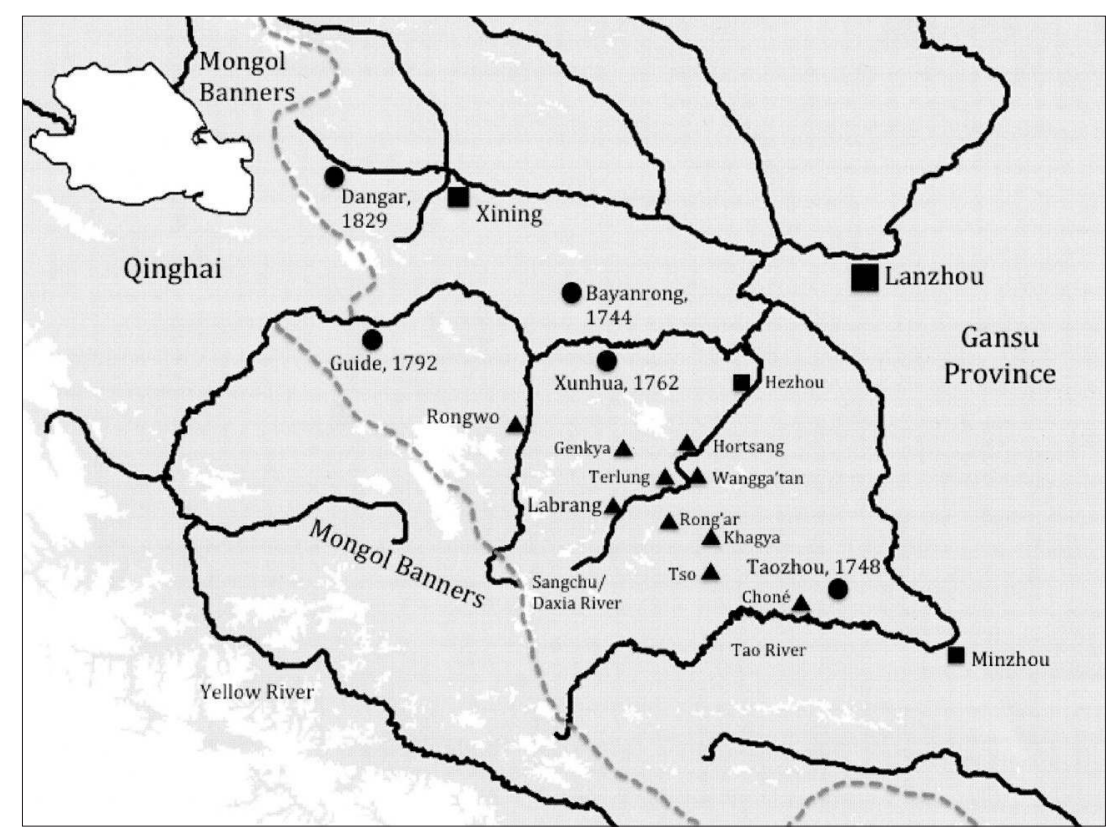

Figure 2. Detailed map of Xunhua subprefecture and vicinity during the Guangzu period (1875-1908)

\section{BIBLIOGRAPHY}

ATwood, Christopher P. (2004). The Encyclopedia of Mongolia and the Mongol Empire. New York, NY: Fact on File.

Benton, Lauren (2002). Law and Colonial Cultures: Legal Regimes in World History, 1400-1900. Cambridge UK: Cambridge University Press.

BEnTON, Lauren (2012). "Forum on Law and Empire in Global Perspective: Introduction." American Historical Review 117.4: 1092-1100.

Brag dgon pa dkon mchog bstan pa rab rgyas (1987 [1865]). Mdo smad chos 'byung (Deb ther rgya mtsho) [The oceanic book]. Zi ling: Mtsho sngon mi rigs dpe skrun khang.

BROPHY, David (2013). "The Junghar Mongol Legacy and the Language of Loyalty in Qing Xinjiang." Harvard Journal of Asiatic Studies 73.2: 231-258.

CoHn, Bernard S. (1996). Colonialism and its Forms of Knowledge. Princeton: Princeton University Press.

Dbang chen skyabs [Wangchen Kyab] (1848). Deb ther mes po zhal lung or Deb ther 'breng po [Book of lessons from the ancestors]. Edited and reconstituted by Shing bza' skal bzang chos kyi rgyal mtshan. Author's collection. 


\section{Max Oidtmann}

Dbal mang dkon mchog rgyal mtshan (1987 [1800]). blab rang bkra shis 'khyil gyi gdan rabs lha'i rnga chen [Gazetteer of Labrang Trashi Khyil Monastery]. Lanzhou: Gansu minzu chubanshe.

Dbal mang dkon mchog rgyal mtshan (1974 [1809-1820]). Rgya bod hor sog gyi lo rgyus nyung brjod pa byis pa 'jug pa'i 'bab stegs [A history of India, Tibet, and Mongolia]. In The Collected Works of Dbal-man dkon-mchog-rgyal-mtshan,d reproduced by Gyaltan Gelek Namgyal, vol. 4 ( $n g a)$. Delhi: New Laxmi Printers.

Dbang chen skyabs. Deb ther mes po zhal lung or Deb ther 'breng po ["Book of Lessons From the Ancestors"]. Unpublished manuscript.

Di Cosmo, Nicola (1998). "Qing Colonial Administration in Inner Asia." The International History Review 20.2: 287-309.

GoNG, Jinghan 龔景瀚 (1981 [1792]). Xunhua zhi 循化志 [Xunhua Gazetteer]. Xining: Qinghai renmin chubanshe.

Hermes, Katherine A. (2008). "The Law of Native Americans, to 1815." In The Cambridge History of Law in America, Vol. I: Early America, 1580-1815, edited by Michael Grossberg and Christopher TomLins, 32-62. Cambridge: Cambridge University Press.

Hostetler, Laura (2001). Qing Colonial Enterprise. Chicago: University of Chicago Press.

'Jig med phrin las rgya mtsho (ca. 1916). Zhva ser ring lugs pa skal bzang thub bstan dbang phyug gi rtogs pa brjod pa rinchen phreng ba,[Biography of Jamyang Zhepa 04, 2 vols.] Labrang: Labrang Monastery Printing House (reprint).

Kangxi Huangyu Quanlantu 康熙皇輿全覽圖 (2007). In WANG Qianjin 汪前進, LIU Ruofang 劉若芳, eds. Qingting sanda shice quantuji 清廷三大實測全圖集. Beijing: Waiwen chubanshe.

MAKLEY, Charlene E. (2007). The Violence of Liberation: Gender and Tibetan Buddhist revival in post-Mao China. Berkeley, Los Angeles \& London: University of California Press.

MORRISON, Alexander (2015). "Creating a Colonial Shari'a for Russian Turkestan," in Imperial Cooperation and Transfer, 1870-1930, edited by Volker BARTH and Roland CVETKOVSKI, 127-149. London: Bloomsbury.

NiAN Gengyao 年美堯 (1971). Nian Gengyao Zouzhe Zhuanji 年美堯奏摺專輯 [Collected memorials of Nian Gengyao], 3 vols. Taibei: Guoli Gugong Bowuyuan.

NIETUPSKI, Paul Kocot (2011). Labrang Monastery: A Tibetan Buddhist Community on the Inner Asian Borderlands, 1709-1958. Lanham: Lexington Books.

Oidtmann, Max (2014). "Between Patron and Priest: Amdo Tibet under Qing Rule, 1791-1911.” Ph.D. Diss., Harvard University.

OidTMAnn, Max (forthcoming). “To Be 'One's Own Master': Qing Statecraft, Gelukpa Historians, and the Shifting Polemics of Empire in 19th century Qinghai," Late Imperial China.

PERduE, Peter (1998). "Comparing Empires: Manchu Colonialism.” The International History Review 20.2: 255-262.

PERDUE, Peter (2009). "China and Other Colonial Empires." The Journal of AmericanEast Asian Relations 16.1-2: 85-103. 
PIRIE, Fernanda (2006). "Legal Complexity on the Tibetan Plateau." Journal of Legal Pluralism 53-54: 80-1.

QSDG. Qinghai sheng dang'anguan Xunhua ting dang'an 青海省档案馆循化厅档 [Archive of Xunhua Subprefecture]. Qinghai Provincial Archives, Xining.

SARTORI, Paolo (2014). "Constructing Colonial Legality in Central Asia." Comparative Studies in Society \& History 56.2: 419-47.

SARTORI, Paolo (2009). "Behind a Petition: Why Muslims' Appeals Increased in Turkestan under Russian Rule.” Asiatische Studien 63.2: 401-34.

SchAefFER, Kurtis R., Matthew T. KAPSTEIN, and Gray TutTLE, editors (2013). Sources of Tibetan Tradition. New York: Columbia University Press.

ScotT, James C. (1998). Seeing Like A State. New Haven: Yale University Press.

SnEATH, David (2007). The Headless State: Aristocratic Orders, Kinship Society, \& Misrepresentations of Nomadic Inner Asia. New York: Columbia University Press.

SoNG, Tingsheng 宋挺生 ed. (1997). Nayancheng Qinghai zouyi 那彦成青海奏 [Nayanceng's memorials from Qinghai]. Xining: Qinghai minzu chubanshe.

Sullivan, Brenton (2015). "Monastic Customaries and the Promotion of Dge Lugs Scholasticism in Amdo and Beyond." Asian Highlands Perspectives 36: 82-105.

TAO, Baolian 陶保廉 (2002 [1896]). Xingmao shixing ji 辛印侍行记 [Account of travels undertaken during the Xingmao year]. Lanzhou: Gansu minzu chubanshe.

Xiangzha Gabuzang 香札尔布藏, editor; Duojie Renqing 多杰仁青, translator (2008). Xianzu Yanjiao 先祖言教 [Lessons of the ancestors]. Xining: Qinghai minzu chubanshe.

Xining Qinghai fanyi cheng li 西寧青海番夷成例 [Regulations of the Fan and Yi of Xining Qinghai] (1994 [1809]). In Zhongguo zhenxi falü dianji jicheng bing bian 中国珍稀法律典籍集成丙编 [Collection of rare laws and regulations] vol. 2. Beijing: Kexue chubanshe.

YANG, Hongwei 杨红伟 (2009). “Zhishi yu zhixu: Gansu Xunhua ting Zangqu quanli jizhi yanjiu 知识与秩序：甘肃循化厅藏区权力机制研究” [Knowledge and order: research on the mechanisms of power in the Tibetan areas of Gansu Xunhua subprefecture]. Ph.D. diss., Lanzhou University.

YANG, Hongwei 杨红伟 and Max OIDTMAnN (2015). “A Study of Qing Dynasty 'Xiejia' Rest Houses in Xunhua Subprefecture, Gansu." In Muslims in Amdo Tibetan Society: Multi-Disciplinary Approaches, edited by Paul NIETUPSKI, Bianca HorlemAnN, and Marie-Paule HiLle, 21-46. Lanham: Lexington Books.

ZHOU Ta 洲塔, and CHEN Xiaoqiang 陈小强 (1994). De'erlongsi yu libei saicang huofo 德尔隆寺与历辈赛仓活佛 [History of Terlung monastery and the Serkhri lineage]. Beijing: Zhongguo zangxue chubanshe.

ZHOU, Xiwu 周希武 (1986). Yushu diaocha ji 玉樹調查記 [Record of survey of Yushu]. Xining: Qinghai renmin chubanshe.

Zuo, Zongtang 左宗棠 (1979). Zuo Wenxiang quanji 左文襄全集 [Collected writings of Zuo Zongtang]. Taibei: Wenhai chubanshe. 


\section{Max Oidtmann}

\section{GLOSSARY}

A-qiong trülku (Tib.) A skyong sprul sku, 阿琼活佛 or lama A-qun 喇嘛阿群 Amchok (Tib.) A mchog, 阿木辍乎

angsuo 昂鎖 or 昂索

baitupo an 白土坡案

baixing 百姓

Bayanrong'ge 巴燕戎格

Belmang Pandita Könchok Gyeltsen (Tib.) Dbal mang Dkon mchog rgyal mtshan, bing 禀

Bora (Tib.) Bo ra, 波拉

Cangyun 長戴

chu kou 出口

Danai 達勇

Danga'er 丹噶爾

Dangang 旦剛 / 當剛, also Danguo zhuang 丹果庄, or Dengguo zhuang 登果庄 dianhu 佃戶

duan 斷

duanjie 斷結

Fan 番

Fan gui 番規

Fan li 番例

Fan su 番俗

Fanzi lüli 番子律例

fenfu 吩咐

Fufan tongzhi 撫番同知

ganjie 甘結

Gansu guan neiwai ji Qinghai 甘肅關內外及青海

ge guan ge si 各管各寺

Gong Jinghan 龔景瀚

Guide 貴德

Guola si 果拉寺

Guomang zhacang 郭芒札倉

Gyangro lama (Tib.) Bla ma 'gyang ro, 江落喇嘛

Han guan 漢官

Hezhou 河州

hongbu 紅布

Hortsang (Tib.) Hor gtsang, 火力藏

houbu zhixian 候補知縣

huangjiao 黃教 
Qing Jurispractices and the Legal Inscription of Piety in Amdo

Jamyang Zhepa (Tib.) 'Jam dbyangs bzhad pa, 嘉木樣呼圖克圖

jieguo 結果

junwang 郡王

Khagya Monastery (Tib.) Kha gya, 卡家寺

Labrang Monastery (Tib.) Bla brang bkra shis 'khyil, 拉卜楞寺 or 會覺寺

Labula 拉布拉 or 拉卜拉

Labula si 拉不拉寺

liang fan 糧番

Lubsang-Danzin 羅卜藏丹津

Mama'erli 馬麻二力

Martai 馬爾泰

Menggu li 蒙古例

Mewu (Tib.) Smad ma 買吾

Nakchu (Tib.) Nag chu, 納克舒

Nanlagongse si 南拉貢色寺

neidi liangmin 內地糧民

nieliwa 捏力哇

Nian Gengyao 年美堯

Pöntsang Lumogya (Tib.) dpon tshang klu mo rgyal, 還倉錄毛加/ 利毛加

Qiexiantan 且先灘

Qilao 七老

Qinghai sheng dang'anguan Xunhua ting dang'an 青海省档案馆循化厅档案

qinwang 親王

Rong'ar (Tib.) rong ngar mi 'gyur gsang sngags gling, 隆哇

Rongwo Monastery (Tib.) Rong bo dgon chen, 隆務寺

Sétsang Lama (Tib.) Bse tshang bla ma Blo bzang bkra shi rab rgyas, 塞倉/歲倉/夕

倉

Shartsang Lama (Tib.) Shar tsang, 沙力倉

shuantou 栓/拴頭

shuantou guanxi 栓頭關係

Sigou 寺溝

Tanggute zi 唐古特字

Tao Baolian 陶保廉

Tao Mo 陶模

Taozhou 洮州

Terlung monastery (Tib.) Gter lung dgon pa, 沙溝寺

ting 廳

tongpan 通判

tongzhi 同知

Trashi Wanggyel (Tib.) bkra shis dbang rgyal, 達錫旺扎勒 


\section{Max Oidtmann}

trülku (Tib.) sprul sku 活佛

Tsö monastery (Tib.) Gtso dga' ldan chos gling, 黑錯寺

Wangchen Kyab (Tib.) Dbang chen skyabs

wang fa 王法

Wangga'tan 汪尔灘

Wenfu 文孚

xiangyue 鄉約

“xiaodemen shi Fanzi, gou yao gou de, bu dong lixing li, qiu she'en li!” 小的们是番 子, 狗咬狗的, 不懂理性哩, 求施恩哩

xiao diming 小地名

xiejia 歇家

Xingmao shixing $j i$ 辛卯侍行记

Xining Qinghai Fanyi cheng $l i$ 西寧青海番夷成例

Xunhua zhi 循化志

Yushu (Tib.) Yul shu, 玉樹

Yushu diaocha ji 玉樹調查記

zai tingdi er fei ting suoshu 在廳地而非廳所屬

zangmin 藏民

Zangzu 藏族

Zhanguo 戰國

Zhang Shixi 張時熙

Zhongguo diyi lishi dang'anguan Manwen lufu 中國第一歷史檔案館滿文錄副

Zhou Xiwu 周希武

zongguan 總管

zuozhu 作主

Zuo Zongtang 左宗棠 